\title{
PENDUGAAN UMUR SIMPAN SIRUP TEMULAWAK (Curcuma xanthorrhiza Roxb), MADU DAN EKSTRAK IKAN GABUS (Ophiocephalus striatus) DENGAN MODEL ARRHENIUS DAN MODEL $\mathbf{Q}_{10}$
}

\section{SAVE AGE PREDICTION OF TEMULAWAK (Curcuma Roxb xanthorrhiza), HONEY AND EXTRACT CORK FISH (Ophiocephalus striatus) SYRUP WITH ARRHENIUS AND $Q_{10}$ MODELS}

\author{
I Komang Suwita ${ }^{1 *}$, Yohanes Kristianto ${ }^{1}$, Firdha Yuniar Purwaningsih ${ }^{2}$ \\ ${ }^{1}$ Staf Pengajar Jurusan Gizi Politeknik Kesehatan Kemenkes Malang \\ ${ }^{2}$ Alumni Jurusan Gizi Politeknik Kesehatan Kemenkes Malang \\ J. Besar Ijen 77C Malang \\ *Penulis korespondensi : Email ksuwita@gmail.com
}

\begin{abstract}
ABSTRAK
Penelitian ini bertujuan untuk mengetahui estimasi (pendugaan) umur simpan sirup (sirup temulawak madu dan ekstrak ikan gabus) berdasarkan parameter total padatan terlarut, $\mathrm{pH}$ dan jumlah mikroorganisme. Jenis penelitian ini adalah eksperimen laboratorium dengan desain percobaan Rancangan Acak Lengkap menggunakan 3 taraf perlakuan yaitu suhu penyimpanan sirup pada $5^{\circ} \mathrm{C}\left(\mathrm{P}_{0}\right)$, $25^{\circ} \mathrm{C}\left(\mathrm{P}_{1}\right)$, dan $35^{\circ} \mathrm{C}\left(\mathrm{P}_{2}\right)$. Hasil penelitian menunjukkan bahwa semakin lama penyimpanan maka nilai total padatan terlarut sirup semakin menurun dari rata-rata 63,43\%Brix menjadi rata-rata 57\%Brix. Nilai $\mathrm{pH}$ menunjukkan semakin meningkat yaitu rata-rata berkisar 5,31-6,6. Sedangkan jumlah mikroorganisme menunjukkan semakin lama penyimpanan, jumlah total mikroorganisme sirup semakin meningkat yaitu 2,6x10 hingga $7,6 \times 10^{2}$ koloni/g. Estimasi umur simpan sirup dengan menggunakan model Arrhenius didapatkan umur simpan sirup yang disimpan pada suhu $5^{\circ} \mathrm{C}\left(9\right.$ hari), $25^{\circ} \mathrm{C}$ ( 3 hari) dan $35^{\circ} \mathrm{C}$ (1 hari). Sedangkan estimasi umur simpan dengan menggunakan model $\mathrm{Q}_{10}$ untuk sirup yang disimpan pada suhu beku yang diasumsikan sebagai suhu penyimpanan untuk pendistribusian produk didapatkan masa kadaluarsa produk sirup pada suhu $-5^{\circ} \mathrm{C}(18$ hari $)$ dan suhu $0^{\circ} \mathrm{C}$ (12 hari). Secara statistik, penyimpanan sirup pada minggu pertama pada suhu $5^{\circ} \mathrm{C}, 25^{\circ} \mathrm{C}, 35^{\circ} \mathrm{C}$ memberikan pengaruh yang signifikan $(\mathrm{p}=0,000)$ terhadap total padatan. Demikian juga, suhu penyimpanan memberikan pengaruh yang signifikan $(\mathrm{p}=0,001)$ terhadap $\mathrm{pH}$ sirup. Namun laju peningkatan jumlah total mikroorganisme pada sirup, baik pada minggu kedua $(\mathrm{P}=0,382)$, minggu ketiga $(\mathrm{p}=0,419)$ dan keempat $(\mathrm{p}=0,256)$. masing-masing secara statistik tidak menunjukan perbedaan yang signifikan.
\end{abstract}

Kata Kunci : umur simpan, sirup, arrhenius, $Q_{10}$.

\begin{abstract}
This study aims to determine the estimation (prediction) shelf life syrup (syrup of ginger, honey and extract of cork fish) based on the parameters of total dissolved solids, $\mathrm{pH}$ and amount of microorganisms. This research was a laboratory experiment with a completely randomized design, using 3 stage treatment that the storage temperature syrup is at $5{ }^{\circ} \mathrm{C}(\mathrm{P} 0), 25^{\circ} \mathrm{C}(\mathrm{P} 1)$, and $35^{\circ} \mathrm{C}(\mathrm{P} 2)$. The results showed that the longer the storage, the value of total dissolved solids syrup has declined from an average of $63.43 \%$ Brix to an average 57\% Brix. The $\mathrm{pH}$ values indicate that increasing average ranged from 5.31 to 6.6. While the number of microorganisms showed the longer the storage, the total number of microorganisms syrup which increases is 2,6 X10 $0^{1}$ to $7.6 \times 10^{2}$ colonies/g. Estimated shelf life syrup was obtained using the Arrhenius model of shelf life syrup stored at a temperature of $5{ }^{\circ} \mathrm{C}\left(9\right.$ days), $25^{\circ} \mathrm{C}$ ( 3 days) and $35^{\circ} \mathrm{C}(1$ day). While the shelf life estimation using model $Q_{10}$ for syrup stored at freezing temperatures are assumed to be a temperature for storage product distribution obtained syrup product shelf life at a temperature of $-5{ }^{\circ} \mathrm{C}$ (18 days) and temperature $0^{\circ} \mathrm{C}$ (12 days). Statistically, syrup in the first week of storage at a temperature of $5^{\circ} \mathrm{C}, 25^{\circ} \mathrm{C}, 35^{\circ} \mathrm{C}$ had a significant influence $(\mathrm{p}=0.000)$ for total solids. Likewise, storage temperature had a significant influence $(p=0.001)$ for $p H$ syrup. However, the rate of increase in the total number of microorganisms in the syrup, both in the second week $(P=.382)$, third week $(p=0.419)$ and fourth $(p=0.256)$. respectively showed no a statistically significant difference.
\end{abstract}

Keywords: shelf life, syrup, Arrhenius, $Q_{10}$ 


\section{PENDAHULUAN}

Telah ada penelitian mengenai proses pengolahan sirup temulawak, madu, dan ekstrak ikan gabus dengan menggunakan metode vakum evaporasi, akan tetapi belum menyentuh aspek penyimpanannya. Produk ini adalah suatu produk baru yang berpotensi menembus pasar dengan promosi sebagai produk untuk meningkatkan nafsu makan pada anak karena terdiri dari beberapa bahan yang berfungsi mengaktifkan enzim sehingga mampu meningkatkan nafsu makan anak.

Temulawak mempunyai manfaat yang sangat besar antara lain meningkatkan nafsu makan, anti kolesterol, antiinflamasi, antianemia, antioksidan, pencegah kanker, dan anti mikroba (Sidik dkk, 1985). Sedangkan dari hasil penelitian Widodo (2001), peneliti di Pusat Penelitian dan Pengembangan Gizi Bogor ditemukan bahwa konsumsi madu secara rutin dapat mengurangi kepekaan terhadap rasa sakit, sekaligus memperbaiki nafsu makan. Dalam ekstrak ikan gabus terdapat albumin yang merupakan protein plasma yang paling tinggi jumlahnya sekitar $60 \%$ dan memiliki berbagai fungsi yang sangat penting bagi kesehatan diantaranya yaitu pembentukan jaringan sel baru dan mempercepat pemulihan jaringan sel tubuh yang rusak (Rusli dkk, 2006).

Umur simpan merupakan selang waktu antara bahan pangan mulai diproduksi hingga tidak dapat diterima lagi oleh konsumen akibat adanya penyimpangan mutu (Histifarina, 2004). Adanya perubahan selama penyimpanan akan mempengaruhi mutu makanan. Stabilitas produk pangan berhubungan dengan mudah tidaknya produk pangan mengalami kerusakan akibat terjadinya perubahan kimia, fisik, dan mikrobiologi. Kerusakan yang dapat terjadi adalah reaksi oksidasi, baik selama proses pengolahan maupun penyimpanan. Hal ini ditandai oleh adanya perubahan warna, aroma, flavour, dan nilai gizi (Hadziyev dan Steele, 1979 dalam Histifarina D, 2004). Umur simpan dapat diukur antara lain dengan $\mathrm{pH}$ karena indikator perubahan enzim adalah $\mathrm{pH}$. Enzim yang ada pada bahan pangan dapat berasal dari mikroba atau memang ada pada bahan pangan tersebut secara normal. Enzim ini memungkinkan terjadinya reaksi kimia dengan lebih cepat tergantung dari enzim yang ada dan dapat mengakibatkan bermacam - macam perubahan pada komposisi bahan pangan dan mikroorganisme karena cemaran mikroorganisme merupakan indikator suatu pangan itu layak dikonsumsi atau tidak. Kerusakan mikrobiologis merupakan bentuk kerusakan yang merugikan serta kadang - kadang berbahaya terhadap kesehatan manusia, karena racun yang diproduksi, penularan serta penjalaran kerusakan yang cepat (Muchtadi, 2010).

Kendala yang sering dihadapi oleh industri pangan dalam penentuan umur simpan suatu produk adalah masalah waktu, oleh karena itu diperlukan metode pendugaan umur simpan cepat, mudah, murah, dan mendekati umur simpan yang sebenarnya (Herawati, 2008). Metode pendugaan umur simpan dapat dilakukan dengan metode Accelerated Shelf-Life Testing (ASLT) yaitu dengan cara menyimpan produk pangan pada lingkungan yang menyebabkannya cepat rusak baik pada suhu atau kelembaban ruang penyimpanan yang lebih tinggi. Metode akselerasi dapat dilakukan dalam waktu yang lebih singkat dengan akurasi yang baik. Metode ASLT model Arrhenius banyak 
digunakan untuk pendugaan umur simpan produk pangan yang mudah rusak oleh reaksi kimia, seperti oksidasi lemak, reaksi Maillard, denaturasi protein dan sebagainya. Secara umum, laju reaksi kimia akan semakin cepat pada suhu yang lebih tinggi yang berarti penurunan produk semakin cepat terjadi. Produk pangan yang dapat ditentukan umur simpannya denga model Arrhenius diantaranya adalah makanan kaleng steril komersial, susu UHT, susu bubuk/formula, produk chip/snack, jus buah, mie instan, frozen meat dan produk pangan lain yang mengandung lemak tinggi (berpotensi terjadinya oksidasi lemak), atau yang mengandung gula pereduksi dan protein (berpotensi terjadinya reaksi kecoklatan) (Kusnandar, 2010).

Model $\mathrm{Q}_{10}$ adalah pemanfaatan lebih lanjut dari model Arrhenius. Model ini dipakai untuk menduga berapa besar perubahan laju reaksi oksidasi atau laju penurunan mutu produk makanan jika produk tersebut disimpan pada suhu - suhu tertentu. Dengan demikian model ini dapat digunakan untuk menduga masa kadaluarsa produk makanan tertentu yang disimpan pada berbagai suhu (Syarief dan Halid, 1993).

Menurut Syarief dan Halid (1993), suhu merupakan faktor yang berpengaruh terhadap perubahan mutu produk pangan. Dalam penyimpanan makanan, keadaan suhu ruangan penyimpanan selayaknya dalam keadaan tetap dari waktu ke waktu. Apabila keadaan suhu peyimpanan tetap (atau dianggap tetap) maka perumusan masalahnya bisa sederhana, yaitu untuk menduga laju penurunan mutu cukup dengan menggunakan persamaan Arrhenius dan dilanjutkan dengan model $\mathrm{Q}_{10}$. Oleh karena itu, perlu dilakukan penelitian tentang estimasi umur simpan dengan menggunakan model Arrhenius dan $\mathrm{Q}_{10}$ untuk memberikan informasi mengenai suhu dan waktu yang tepat dalam penyimpanan sirup temulawak, madu, dan ekstrak ikan gabus.

Tujuan penelitian ini yaitu untuk : mengetahui estimasi (pendugaan) umur simpan sirup temulawak (Curcuma xanthorrhiza Roxb), madu dan ekstrak ikan gabus (Ophiocephalus striatus), meliputi; menganalisis total padatan, $\mathrm{pH}$, dan total mikroba pada sirup temulawak, madu dan ekstrak ikan gabus yang telah disimpan pada suhu $5^{\circ} \mathrm{C}, 25^{\circ} \mathrm{C}$, dan $35^{\circ} \mathrm{C}$.

\section{METODE PENELITIAN}

Penelitian ini dilaksanakan pada bulan Desember 2011 - Maret 2012 di Laboratorium Ilmu Bahan Makanan (IBM) dan Laboratorium Ilmu Teknologi Pangan (ITP) Jurusan Gizi Politeknik Kesehatan Kemenkes Malang untuk pengolahan, pegujian total padatan terlarut, $\mathrm{pH}$ dan penyimpanan sirup temulawak, madu dan ekstrak ikan gabus. Laboratorium Kualitas Air Jasa Tirta I Malang untuk pengujian total mikroba.

Bahan yang dibutuhkan untuk membuat sirup temulawak, madu, dan ekstrak ikan gabus adalah : temulawak, madu, ekstrak ikan gabus

Bahan yang digunakan untuk analisis padatan, $\mathrm{pH}$ dan uji total mikroba: sampel sirup, agar cawan, PCA, aquades dan alkohol 95\%.

Alat-alat yang digunakan dalam penelitian ini: baskom, pisau, parutan, thermometer, talenan, dandang, panci, piring gelas ukur, kain saring, vacum evaporator, botol, inkubator, refrigerator, pipet volume, cawan petri, tabung reaksi, jarum ose, batang pengoles, Erlenmeyer, beker glas, autoklaf, oven kering, timbangan digital, dispenser, hot plate, penangas 
air, Quebec Colony Counter, $\mathrm{pH}$ meter, refraktometer.

Jenis penelitian yang digunakan adalah Eksperimen dengan rancangan penelitian Rancangan Acak Lengkap (RAL) dengan variabel bebas yaitu suhu penyimpanan sirup temulawak, madu, dan ekstrak ikan gabus yang terdiri dari 3 taraf perlakuan, yaitu : $\mathrm{P}_{0}=5^{\circ} \mathrm{C}, \mathrm{P}_{1}=$ $25^{\circ} \mathrm{C}$ dan $\mathrm{P}_{2}=35^{\circ} \mathrm{C}$. Masing-masing taraf perlakuan dilakukan replikasi sebanyak 3 kali, sehingga jumlah unit percobaan adalah 9 unit percobaan.

\section{PELAKSANAAN PENELITIAN}

\section{Pengolahan Sirup Temulawak, Madu dan Ekstrak Ikan Gabus}

Pengolahan sirup dilakukan dengan mengupas temulawak, memarut temulawak, memeras (mengambil sari) temulawak (25 ml), mencampurkan temulawak dengan madu (125 ml), mengukus (steam) selama 5 menit pada suhu $80^{\circ} \mathrm{C}$, mencampurkan dengan albumin (100 ml), melakukan pemanasan selama 15 menit pada suhu $50^{\circ} \mathrm{C}$, melakukan proses vakum evaporasi pada suhu $54^{\circ} \mathrm{C}$.

\section{Pengemasan Sirup Temulawak, Madu dan Ekstrak Ikan Gabus}

Pengemasan sirup dilakukan dengan langkah-kah sebegai berikut: mensterilisasikan botol dengan cara direbus selama 30 menit, menuang sirup redukut pada suhu $40^{\circ} \mathrm{C}$ (kondisi hangat) pada botol ukuran $25 \mathrm{ml}$ dan selanjutnya botol ditutup rapat.

\section{Penyimpanan Sirup Temulawak, Madu dan Ekstrak Ikan Gabus \\ Setelah sirup dimasukan pada botol, selanjutnya menyimpan sirup redukut pada suhu $5^{\circ} \mathrm{C}, 25^{\circ} \mathrm{C}$ dan $35^{\circ}$ C. Sirup disimpan selama 4 minggu dengan pengamatan setiap 1 minggu}

untuk uji total mikroba, $\mathrm{pH}$ dan total padatan terlarut.

\section{Uji Total Mikroba Sirup Temulawak, Madu dan Ekstrak Ikan Gabus}

(Fardiaz, 1993)

Uji total mikroba pada sirup dilakukan setiap minggu berturut-turut selama empat minggu yang diuji menggunakan metode Total Plate Count (TPC).

\section{Uji pH Sirup Temulawak, Madu dan} Ekstrak Ikan Gabus

Uji pH sirup dilakukan setiap minggu berturut-turut selama empat minggu yang diuji menggunakan $\mathrm{pH}$ meter (Standar Operasional Prosedur Laboratorium)

Uji Total Padatan Terlarut Sirup Temulawak, Madu dan Ekstrak Ikan Gabus

Untuk mengetahui total padatan pada sirup, dilakukan uji total padatan setiap minggu berturut-turut selama empat minggu. Uji total padatan dilakukan menggunakan Refraktometer (Standar Operasional Prosedur Laboratorium)

Pengolahan Data Pendugaan Umur Simpan Sirup Temulawak, Madu, Dan Ekstrak Ikan Gabus

Data untuk menghitung pengaruh suhu penyimpanan terhadap total padatan terlarut diolah menggunakan nilai rata - rata total padatan terlarut, yaitu untuk mengetahui perubahan nilai total padatan terlarut yang terjadi pada saat penyimpanan sirup.

Data untuk menghitung pengaruh suhu penyimpanan terhadap $\mathrm{pH}$ diolah menggunakan nilai rata-rata $\mathrm{pH}$, yaitu untuk mengetahui tingkat keasaman pada reaksi enzimatis yang terjadi pada saat penyimpanan sirup temulawak, madu, dan ekstrak ikan gabus. 
Data untuk menghitung pengaruh suhu penyimpanan terhadap total mikroba diolah menggunakan nilai rata - rata jumlah koloni mikroba dalam TPC, yaitu untuk mengetahui banyaknya jumlah mikroorganisme selama peyimpanan sirup temulawak, madu, dan ekstrak ikan gabus.

\section{Analisis Data Pendugaan Umur Simpan Sirup Temulawak, Madu, Dan Ekstrak Ikan Gabus}

Pengaruh suhu penyimpanan terhadap total padatan terlarut, $\mathrm{pH}$ dan total mikroorganisme sirup temulawak, madu, dan ekstrak ikan gabus dianalisis menggunakan uji statistik One Way Anova dengan tingkat kepercayaan 95\%, dan jika perlakuan berpengaruh nyata maka dilanjutkan dengan uji Duncan Multiple Range Test (DMRT). Sedangkan pendugaan umur simpan sirup temulawak, madu, dan ekstrak ikan gabus dianalisis menggunakan model Arrhenius dan $\mathrm{Q}_{10}$ dengan menggunakan persamaan :

$$
\mathbf{k}=\mathbf{k}_{\mathbf{0}} \mathbf{e}^{-\mathrm{E} / \mathbf{R T}}
$$

dimana :

$\mathrm{k}=$ konstanta penurunan mutu

$\mathrm{k}_{0}=$ konstanta (tidak tergantung pada suhu)

$\mathrm{E}=$ energi aktivasi

$\mathrm{T}=$ suhu mutlak $(\mathrm{C}+273)$

$\mathrm{R}=$ konstanta gas, 1.986

$\mathrm{kkal} / \mathrm{mol}$

kemudian dilanjutkan dengan model $\mathrm{Q}_{10}$ dengan rumus :

$$
\begin{gathered}
\mathbf{Q}_{10}=\frac{\text { Laju penurunan mutu pada suhu }(T+10)}{\text { Laju penuruman mutu pada suhu } T} \\
=\frac{\operatorname{ts}(T)}{\operatorname{ts}(T+10)}
\end{gathered}
$$

dimana :

$\mathrm{T}$ : suhu penyimpanan dalam ${ }^{\circ} \mathrm{C}$

ts(T) : masa kadaluarsa jika disimpan pada suhu $\mathrm{T}$

ts $(\mathrm{T}+10)$ : masa kadaluarasa jika

disimpan pada suhu $\mathrm{T}+10$
Analisis mutu sensori sirup temulawak, madu, dan ekstrak ikan gabus

Data mutu sirup temulawak, madu dan ekstrak ikan gabus secara sensori yang meliputi warna, aroma, dan tekstur dianalisis secara deskriptif.

\section{HASIL DAN PEMBAHASAN}

\section{Gambaran Umum Produk}

Pengolahan sirup ini dilakukan dengan menggunakan metode vakum evaporasi pada suhu $55^{\circ} \mathrm{C}$ dan tekanan $-25 \mathrm{cmHg}$ atau setara dengan -0,328 atm dengan lama waktu yang digunakan adalah 4 jam. Sirup yang telah diolah kemudian disimpan selama 4 minggu (28 hari) pada 3 macam suhu yang berbeda yaitu suhu $5^{\circ} \mathrm{C}$ yang disimpan pada refrigerator, suhu $25^{\circ} \mathrm{C}$ yang disimpan pada suhu ruang, dan suhu $35^{\circ} \mathrm{C}$ yang disimpan pada inkubator. Hasil sirup yang disimpan pada suhu yang berbeda dengan waktu penyimpanan yang sama menunjukkan adanya perbedaan pada karakteristik produk yang disajikan pada Tabel 1.

\section{Total Padatan Terlarut Sirup}

Nilai total padatan terlarut sirup temulawak, madu dan ekstrak ikan gabus diperoleh dari hasil penyimpanan sirup selama 4 minggu yang disimpan pada 3 suhu penyimpanan berkisar 54,6 - 63,43\%Brix. Hasil analisis menunjukkan bahwa semakin lama penyimpanan maka nilai total padatan terlarut sirup temulawak, madu dan ekstrak ikan gabus cenderung semakin menurun, sebagaimana disajikan pada Gambar 1. 
Tabel 1. Karakteristik Produk Sirup Temulawak, Madu, dan Ekstrak Ikan Gabus

\begin{tabular}{|c|c|c|c|c|}
\hline \multirow{2}{*}{$\begin{array}{c}\text { Suhu } \\
\text { penyimpanan } \\
\left({ }^{\circ} \mathrm{C}\right)\end{array}$} & \multirow{2}{*}{$\begin{array}{c}\text { Waktu } \\
\text { Penyimpanan }\end{array}$} & \multicolumn{3}{|c|}{ Karakteristik Produk } \\
\hline & & Warna & Aroma & Kekentalan \\
\hline \multirow{4}{*}{$\mathrm{P}_{0}(5)$} & Mg 1 & coklat bening & temulawak segar & kental \\
\hline & $\operatorname{Mg} 2$ & coklat agak bening & temulawak segar & kental \\
\hline & Mg 3 & coklat agak pekat & temulawak & agak kental \\
\hline & $\operatorname{Mg} 4$ & coklat agak pekat & temulawak & sedikit encer \\
\hline \multirow{4}{*}{$P_{1}(25)$} & Mg 1 & coklat agak pekat & temulawak & kental \\
\hline & Mg 2 & coklat pekat & temulawak & agak kental \\
\hline & Mg 3 & coklat pekat & agak tengik & sedikit encer \\
\hline & $\operatorname{Mg} 4$ & coklat pekat & tengik & encer \\
\hline \multirow{4}{*}{$\mathrm{P}_{2}(35)$} & Mg 1 & coklat agak pekat & temulawak & kental \\
\hline & Mg 2 & coklat pekat & agak tengik & sedikit encer \\
\hline & Mg 3 & coklat pekat & agak tengik & sedikit encer \\
\hline & $\operatorname{Mg} 4$ & coklat sangat pekat & tengik & encer \\
\hline
\end{tabular}

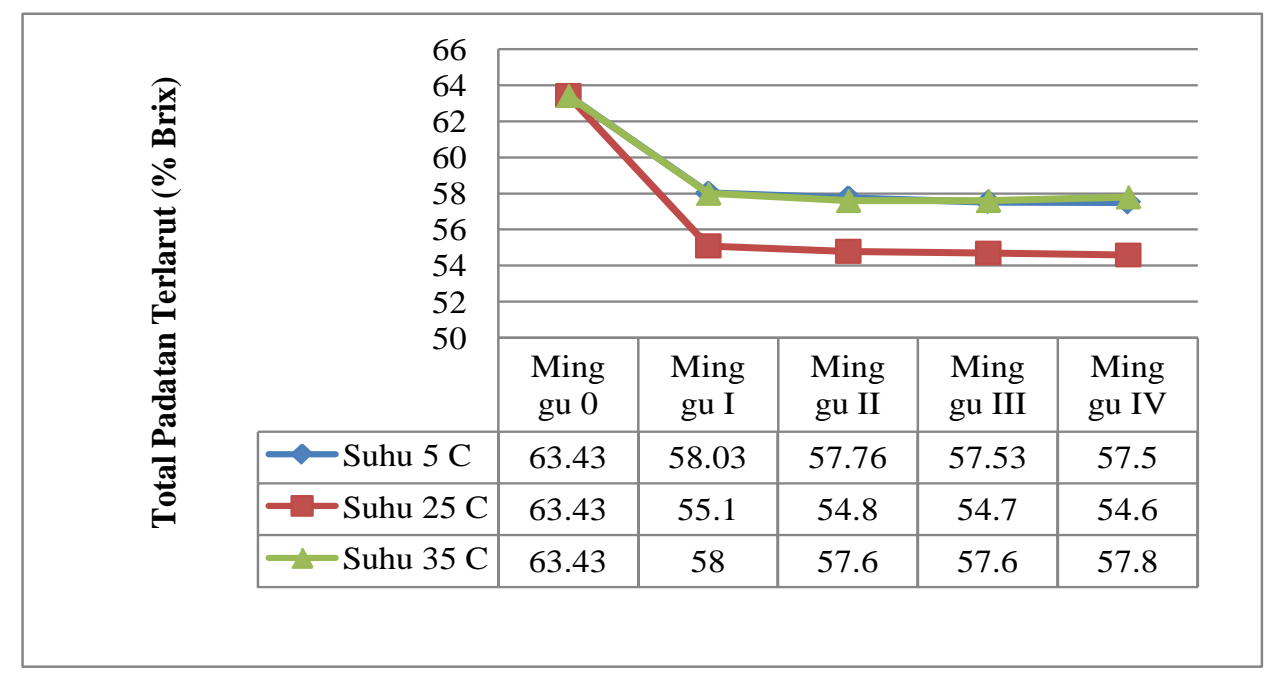

\section{Gambar 1. Rata - rata Total Padatan Terlarut Sirup Temulawak, Madu dan Ekstrak Ikan Gabus Pada Penyimpanan Selama 4 Minggu}

Gambar 1 menunjukkan pada awal penyimpanan, rata-rata total padatan terlarut sirup yang disimpan pada 3 suhu penyimpanan yang berbeda adalah 63,43\%Brix. Penurunan total padatan terlarut berkisar antara 0,1-1\%Brix, penurunan total padatan terlarut tersebut diakibatkan karena adanya pengaruh enzim yang dapat berasal dari mikroba atau memang ada pada bahan pangan tersebut secara normal. Enzim ini memungkinkan terjadinya reaksi kimia dengan lebih cepat tergantung dari enzim yang ada, dan dapat mengakibatkan bermacam-macam perubahan pada komposisi bahan pangan (Muchtadi, 2010). Menurut Dewandari, dkk (2009), penurunan nilai total padatan terlarut seiring dengan lamanya waktu penyimpanan.

Hasil analisis statistik One Way Anova menunjukkan bahwa penyimpanan sirup pada minggu pertama dengan suhu $5^{\circ} \mathrm{C}, 25^{\circ} \mathrm{C}, 35^{\circ} \mathrm{C}$ memberikan pengaruh yang signifikan $(p=0,000)$ terhadap total padatan 
terlarut sirup temulawak, madu dan ekstrak ikan gabus. Begitu juga dengan penyimpanan sirup pada minggu kedua hingga minggu keempat. Hasil analisis lanjut, Duncan Multiple Range Test (DMRT) menujukkan bahwa suhu penyimpanan sirup pada suhu $5^{\circ} \mathrm{C}$ berbeda signifikan dengan sirup yang disimpan pada $25^{\circ} \mathrm{C}$ dan $35^{\circ} \mathrm{C}$, namun perbedaan total padatan terlarut pada suhu $25^{\circ} \mathrm{C}$ dan $35^{\circ} \mathrm{C}$ tidak signifikan.

Secara umum, penurunan nilai total padatan terlarut pada suhu $5^{\circ} \mathrm{C}$ berkisar antara 5\%Brix. Bartolome et al., dalam Dewandari, dkk, (2009) menyebutkan bahwa selama pendinginan, terjadi penurunan minimal kandungan total padatan terlarut. Total padatan terlarut juga dipengaruhi oleh adanya denaturasi protein, protein yang terdenaturasi akan berkurang kelarutannya (Winarno, 2004).

Menurut Standar Nasional Indonesia (SNI) 01-2985-1992 yaitu jumlah padatan pada sirup fruktosa yaitu 70,5-71,5\%Brix, sedangkan sirup temulawak, madu dan ekstrak ikan gabus yang telah dilakukan proses penyimpanan selama 4 minggu menunjukkan bahwa semakin lama disimpan maka total padatan terlarut semakin menurun hingga mencapai $\pm 57 \%$ Brix. Hal ini menunjukkan bahwa adanya kerusakan bahan pangan yang dapat mempengaruhi mutu dan umur simpan produk pangan.

\section{pH Sirup}

Hasil penelitian menunjukkan bahwa nilai $\mathrm{pH}$ sirup yang disimpan pada 3 suhu penyimpanan yang berbeda selama 4 minggu berkisar antara 5,31 - 6,6 sebagaimana pada Gambar 2.

Rata-rata $\mathrm{pH}$ sirup yang disimpan pada 3 suhu penyimpanan yang berbeda adalah 5,31. Peningkatan $\mathrm{pH}$ berkisar antara 0,1-0,8. Hal ini diakibatkan terjadinya reaksi enzimatis yang dapat mempegaruhi perubahan $\mathrm{pH}$. Enzim ini memungkinkan terjadinya reaksi kimia dengan lebih cepat tergantung dari enzim yang ada, dan dapat mengakibatkan bermacam-macam perubahan pada komposisi bahan pangan. Keaktifan maksimum dari enzim pada umumnya pada $\mathrm{pH} 4-8$, atau di sekitar $\mathrm{pH}$ 6, dan $\mathrm{pH}$ menentukan macam mikroba yang tumbuh dalam makanan dan produk yang dihasilkan. Setiap mikroba masing - masing mempunyai $\mathrm{pH}$ optimum, maksimum, dan minimum untuk pertumbuhannya (Muchtadi, 2010).

$\square$

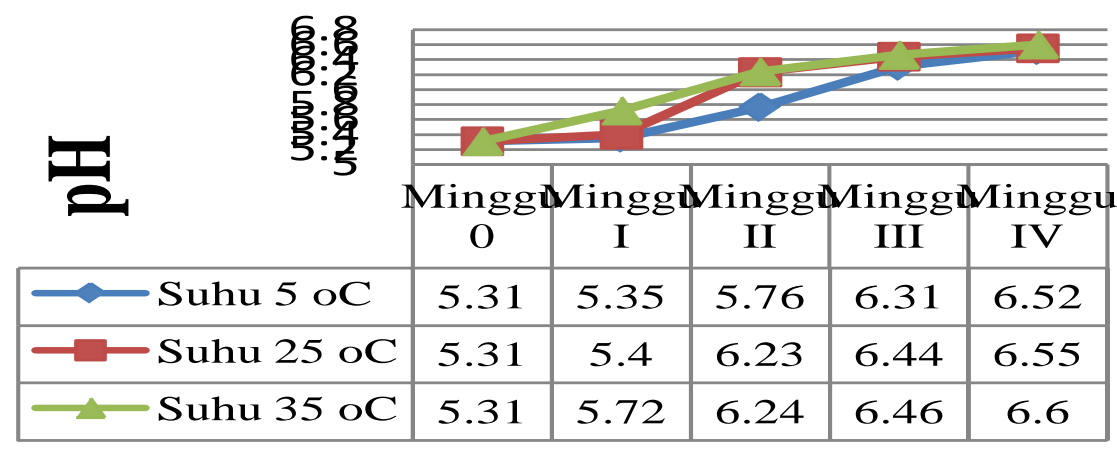

Gambar 2. Rata - rata pH Sirup Temulawak, Madu dan Ekstrak Ikan Gabus Pada Penyimpanan Selama 4 Minggu

$\mathrm{pH}$ sirup semakin lama disimpan berubah menjadi semakin basa, Menurut
Winarno 2004, produk dapat berubah menjadi basa dikarenakan terjadinya 
denaturasi protein, sebagian besar protein globuler mudah mengalami denaturasi yaitu susunan molekulnya berubah yang diiikuti dengan perubahan sifat fisik dan fisiologisnya. Sirup yang disimpan pada suhu $5^{\circ} \mathrm{C}, 25^{\circ} \mathrm{C}$, dan $35^{\circ} \mathrm{C}$ mengalami perubahan $\mathrm{pH}$ setiap minggunya,. Uji statistik menunjukkan bahwa pada minggu pertama suhu penyimpanan sirup memberikan pengaruh yang signifikan $(\mathrm{p}=0,001)$ terhadap $\mathrm{pH}$ sirup. Uji lanjut DMRT menunjukkan bahwa sirup yang disimpan pada suhu $5^{\circ} \mathrm{C}$ dan $25^{\circ} \mathrm{C}$ berbeda signifikan dengan sirup yang disimpan pada suhu $35^{\circ} \mathrm{C}$.

Diungkapkan oleh Fardiaz (1992) bahwa nilai $\mathrm{pH}$ medium sangat mempengaruhi jenis jasad renik yang tumbuh. Jasad renik umumnya dapat tumbuh pada kisaran pH 3-6 unit.

Peningkatan $\mathrm{pH}$ itu dapat menjadi salah satu indikator kerusakan dari sirup, dalam hal ini $\mathrm{pH}$ sirup termasuk dalam $\mathrm{pH}$ berasam rendah (basa). Menurut Standar Nasional Indonesia (SNI) 01-2985-1992, pH pada sirup fruktosa yaitu 3,5 - 4,5, sedangkan selama penyimpanan $\mathrm{pH}$ semakin meningkat hingga 6,5-6,6.

\section{Total Mikroorganisme Sirup}

Hasil penelitian menunjukkan bahwa semakin lama penyimpanan maka jumlah total mikroganisme sirup cenderung semakin meningkat, sebagaimana disajikan pada Gambar 3.

Perhitungan total mikroorganisme menggunakan prinsip hitungan cawan yaitu dengan menggunakan PCA (Plate Count Agar) sebagai suatu medium pemupukan sehingga semua mikroba termasuk bakteri, kapang, dan khamir dapat tumbuh dengan baik pada medium tersebut (Fardiaz, 1993). Gambar 3 menunjukkan rata - rata jumlah total mikroba pada sirup yang disimpan pada suhu $5^{\circ} \mathrm{C}$ lebih sedikit dibandingkan dengan sirup yang disimpan pada suhu tinggi disebabkan karena kebanyakan mikroorganisme tahan terhadap suhu rendah sampai suhu pembekuan dan walaupun pertumbuhan dan pembelahan mungkin terhambat, sel-sel bakteri dapat tahan hidup untuk jangka waktu cukup lama pada suhu pendinginan $\pm 5^{\circ} \mathrm{C}$ (Buckle, 1985).

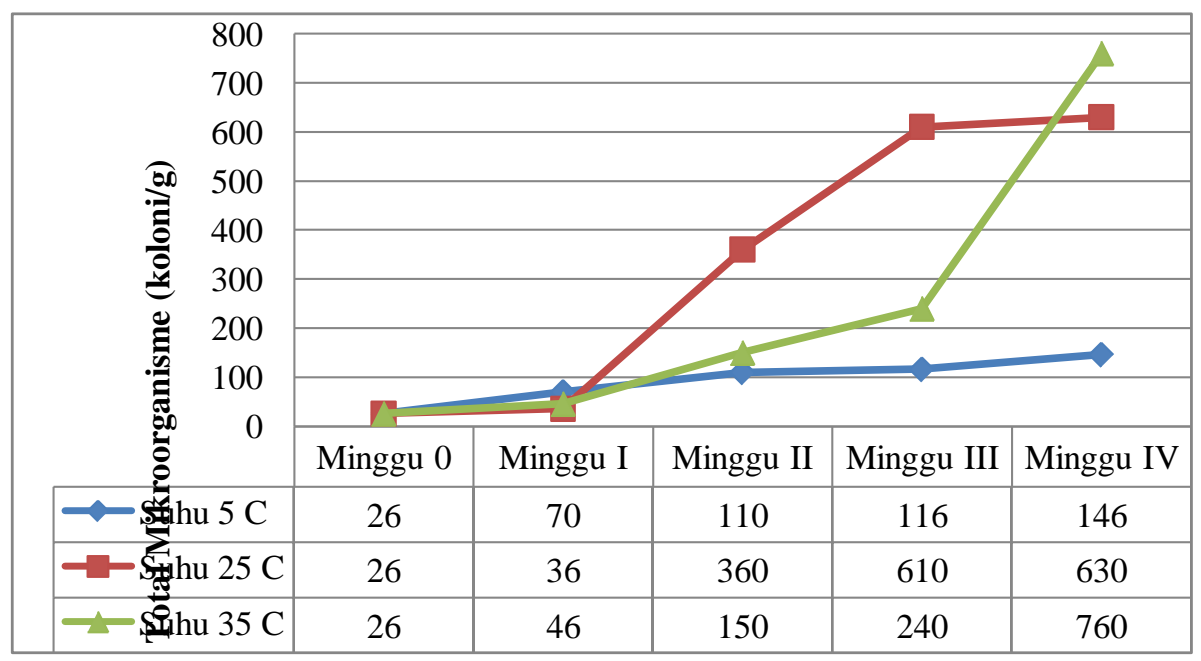

Gambar 3. Rata - rata Jumlah Mikroorganisme Sirup Temulawak, Madu dan Ekstrak Ikan Gabus Pada Penyimpanan Selama 4 Minggu 
Penggunaan suhu rendah dalam pengawetan bahan tidak dapat menyebabkan kematian mikroba sehingga bila bahan pangan dikeluarkan dari tempat penyimpanan dan dibiarkan mencair kembali (thawing) pertumbuhan mikroba pembusuk dapat berjalan dengan cepat (Santoso, 2006). Pendapat serupa oleh Gaman dan Serrington (1992) yaitu suhu di dalam alat pendingin adalah berkisar antara $0-5^{\circ} \mathrm{C}$, pertumbuhan hampir semua mikroorganisme tetap tumbuh lambat pada suhu tersebut dan spora bakteri tetap bertahan hidup.

Rata - rata jumlah total mikroba yang disimpan pada suhu $25^{\circ} \mathrm{C}$ mengalami peningkatan yang sangat cepat disebabkan karena suhu $25^{\circ} \mathrm{C}$ termasuk suhu optimum pertumbuhan mikroba. Berdasarkan suhu optimumnya yaitu antara $20^{\circ} \mathrm{C}-45^{\circ} \mathrm{C}$, kebanyakan bakteri digolongkan dalam bakteri mesofilik, dalam keadaan optimum bakteri memperbanyak diri dengan cepat. Dari satu sel menjadi dua hanya memerlukan waktu 20 menit dan seterusnya tumbuh dan kebanyakan kapang adalah mesofilik dan mempunyai suhu optimum sekitar $25-30^{\circ} \mathrm{C}$ atau suhu kamar (Muctadi, 2010).

Paenyimpanan pada suhu $35^{\circ} \mathrm{C}$ juga terdapat peningkatan jumlah mikroorganisme karena terdapat beberapa kapang yang dapat tumbuh baik pada suhu $35-37^{\circ} \mathrm{C}$, contohnya Aspergillus sp dan beberapa suhu yang lebih tinggi (Muctadi, 2010)..

Pada minggu ke 0 sebelum penyimpanan hingga minggu pertama, laju peningkatan mikroorganisme secara keseluruhan cenderung sama, namun terlihat pada minggu kedua dan minggu ketiga pola pertumbuhannya pada suhu penyimpanan $5^{\circ} \mathrm{C}$ dan $35^{\circ} \mathrm{C}$ cenderung peningkatannya lebih stabil dibandingkan dengan penyimpanan pada suhu $25^{\circ} \mathrm{C}$ (suhu ruang) karena kedua suhu tersebut dapat dikontrol dan stabil setiap harinya. Sedangkan pada suhu ruang, suhunya dapat berubah-ubah (fluktuasi). Tawali, dkk (2004) juga menyatakan bahwa penyimpanan pada suhu ruang (dibiarkan sesuai dengan suhu lingkungan) akan menyebabkan penurunan mutu fisik, kimia dan organoleptik dan mutu gizi sangat cepat yang diikuti proses pembusukan dibandingkan suhu stabil. Gambar 3 menggambarkan perbedaan laju peningkatan jumlah total mikroorganisme pada minggu kedua walaupun secara statistik tidak signifikan $(\mathrm{P}=0,382)$, sama halnya pada minggu ketiga dan keempat dengan masing-masing hasil uji statistik tidak signifikan ( $\mathrm{p}=0,419$ dan $\mathrm{p}=0,256)$.

Menurut Standar Nasional Indonesia (SNI) 01-2985-1992 yaitu cemaran mikroba pada sirup fruktosa adalah maksimal $5,0 \mathrm{x}$ $10^{2}$. Dari data SNI tersebut dapat diketahui bahwa sirup temulawak, madu dan ekstrak ikan gabus yang disimpan pada suhu $5^{\circ} \mathrm{C}$ hingga penyimpanan 4 minggu apabila dilihat dari jumlah total mikroorganisme masih aman untuk dikonsumsi dengan rata rata jumlah total mikroorganisme pada minggu ke empat sebanyak 14,6 x $10^{1}$. Sedangkan sirup yang disimpan pada suhu $25^{\circ} \mathrm{C}$ (total mikroorganisme 6,1 x 10 ${ }^{2}$ ) dan $35^{\circ} \mathrm{C}$ (total mikroorganisme 7,6 x $10^{2}$.) sudah tidak aman untuk dikonsumsi.

\section{Estimasi pendugaan umur simpan berdasarkan laju penurunan total padatan terlarut sirup temulawak, madu dan ekstrak ikan gabus}

Berdasarkan rata-rata perubahan total padatan terlarut selama penyimpanan dapat dibuat grafik dan persamaan garis linier hubungan antara lama penyimpanan dan total padatan terlarut pada tiga suhu penyimpanan. Grafik laju penurunan nilai total padatan terlarut dapat dilihat pada Gambar 4. 


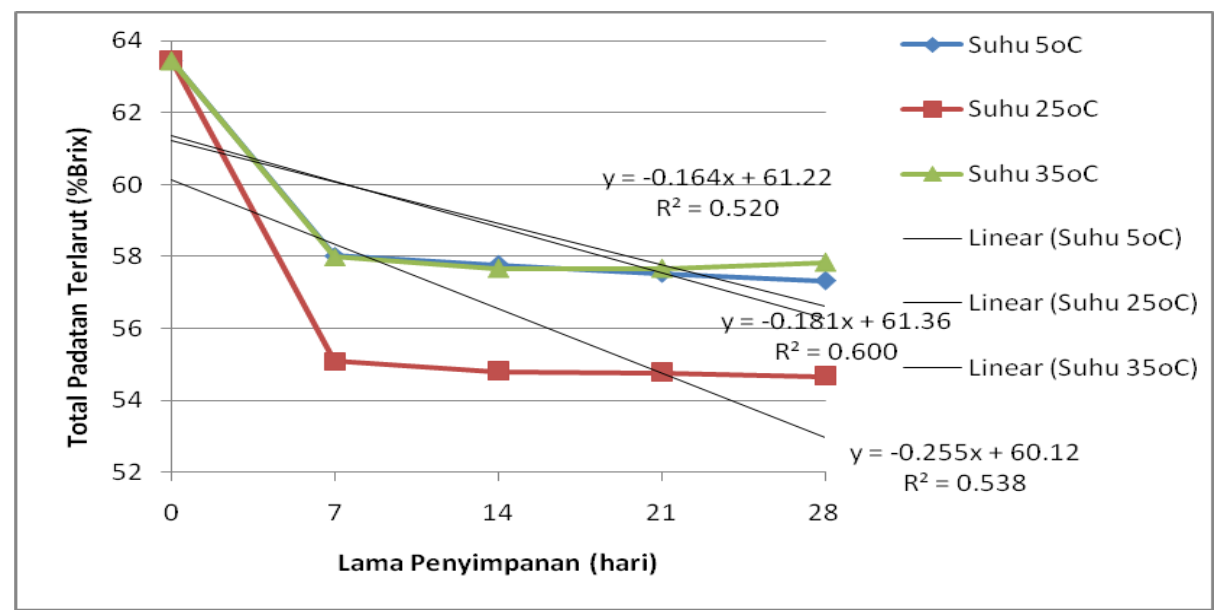

Gambar 4. Grafik Hubungan antara Lama Penyimpanan dengan Total Padatan Terlarut Sirup Temulawak, Madu dan Ekstrak Ikan Gabus

Nilai konstanta penurunan mutu pada ketiga suhu penyimpanan tersebut kemudian diterapkan pada persamaan Arrhenius yaitu $\ln \mathrm{k}=\ln \mathrm{ko}-\mathrm{E} / \mathrm{RT}$. Setiap nilai $\ln \mathrm{k}$ dan $1 / \mathrm{T}$ (satuan suhu dalam Kelvin) pada masing masing suhu penyimpanan diplotkan sebagai ordinat dan absis. Grafik hubungan nilai ln $\mathrm{k}$ dan $1 / \mathrm{T}$ produk sirup dapat dilihat pada Gambar 5. E/R adalah $40,67^{\circ} \mathrm{K}$, jika dikalikan dengan nilai $\mathrm{R}$ (konstanta gas), yaitu 1,986 kal/mol, diperoleh nilai energi aktivasi (E) Dari analisis regresi linear diperoleh persamaan garis $\ln \mathrm{k}=40,67(1 / \mathrm{T})$ $-1,554$ dengan $r=0$.
Nilai intersep merupakan nilai ko dari persamaan Arrhenius, sehingga diperoleh nilai ko (konstanta tidak tergantung suhu) sebesar $0,211400678 \mathrm{mmol} / \mathrm{kg} / \mathrm{hr}$. Jadi persamaan Arrhenius untuk laju perubahan total padatan terlarut sirup temulawak, madu dan ekstrak ikan gabus adalah $\mathrm{k}=$ 0,211400678. $\mathrm{e}^{-}$40,67 x (1/T dalam Kelvin). Berdasarkan persamaan Arrhenius tersebut, dapat ditentukan laju penurunan total padatan terlarut pada berbagai suhu penyimpanan seperti pada Tabel 2.

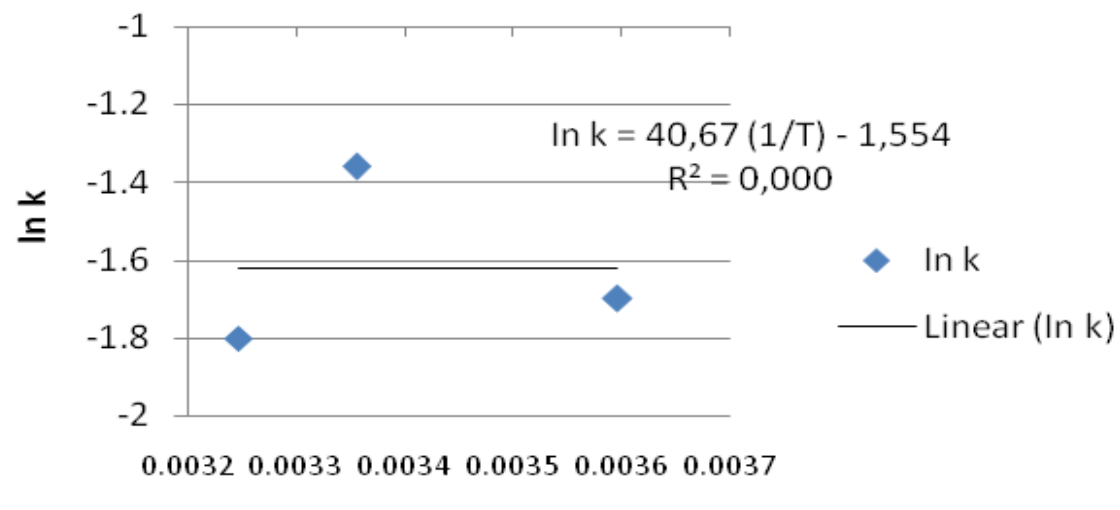

$1 / \mathrm{T}^{\circ} \mathrm{K}$

Gambar 5. Hubungan antara ln k dan 1/T 
Tabel 2. Laju Penurunan Nilai Total Padatan Terlarut Sirup Temulawak, Madu dan Ekstrak Ikan Gabus

\begin{tabular}{ccc}
\hline \multicolumn{1}{c}{ Suhu } & Persamaan & k (\%Brix/ml/hr) \\
\hline $5^{\circ} \mathrm{C}$ atau $278^{\circ} \mathrm{K}$ & $\mathrm{k}=0,211400678 . \mathrm{e}^{-40,6 / \times(1 / 2 / 8)}$ & 0,18268 \\
$25^{\circ} \mathrm{C}$ atau $298^{\circ} \mathrm{K}$ & $\mathrm{k}=0,211400678 . \mathrm{e}^{-40,6 / \times(1 / 298)}$ & 0,18451 \\
$35^{\circ} \mathrm{C}$ atau $308^{\circ} \mathrm{K}$ & $\mathrm{k}=0,211400678 . \mathrm{e}^{-40,67 \times(1 / 308)}$ & 0,18525
\end{tabular}

Perhitungan lebih lanjut dari model Arrhenius adalah model $\mathrm{Q}_{10}$ dan hasil perhitungannya disajikan pada Tabel 3.

Tabel 3. Faktor Percepatan Reaksi $\left(\mathrm{Q}_{10}\right)$ Total Padatan Terlarut Sirup Temulawak, Madu dan Ekstrak Ikan Gabus

\begin{tabular}{lc}
\hline & $\mathbf{Q}_{10}$ \\
\hline$-5^{\circ} \mathrm{C}$ atau $268^{\circ} \mathrm{K}$ & 1,00500 \\
$0^{\circ} \mathrm{C}$ atau $273^{\circ} \mathrm{K}$ & 1,00774 \\
$5^{\circ} \mathrm{C}$ atau $278^{\circ} \mathrm{K}$ & 1,00476 \\
$25^{\circ} \mathrm{C}$ atau $298^{\circ} \mathrm{K}$ & 1,00401 \\
$35^{\circ} \mathrm{C}$ atau $308^{\circ} \mathrm{K}$ & 1,00415 \\
\hline
\end{tabular}

Dengan menggunakan Model $\mathrm{Q}_{10}$ ini dapat dihitung estimasi umur simpan produk dalam berbagai suhu (Syarief dan Halid, 1993).

Perhitungan masa kadaluarsa produk berdasarkan parameter total padatan terlarut yang disimpan pada suhu $-5^{\circ} \mathrm{C}$ dan $0^{\circ} \mathrm{C}$ dengan menggunakan model $\mathrm{Q}_{10}$ relatif sama yaitu 46 hari.

\section{Estimasi pendugaan umur simpan berdasarkan peningkatan $\mathrm{pH}$ sirup temulawak, madu dan ekstrak ikan gabus}

Berdasarkan rata-rata perubahan $\mathrm{pH}$ selama penyimpanan dapat dibuat grafik dan persamaan garis linier hubungan antara lama penyimpanan dan $\mathrm{pH}$ pada tiga suhu penyimpanan. Grafik laju peningkatan nilai total $\mathrm{pH}$ dapat dilihat pada Gambar 6.

Nilai konstanta penurunan mutu pada ketiga suhu penyimpanan tersebut kemudian diterapkan pada persamaan Arrhenius yaitu $\ln \mathrm{k}=\ln \mathrm{ko}-\mathrm{E} / \mathrm{RT}$. Setiap nilai ln $\mathrm{k}$ dan $1 / \mathrm{T}$ (satuan suhu dalam Kelvin) pada masing masing suhu penyimpanan diplotkan sebagai ordinat dan absis. Grafik hubungan nilai ln $\mathrm{k}$ dan $1 / \mathrm{T}$ produk sirup temulawak, madu dan ekstrak ikan gabus dapat dilihat pada gambar 7. Dari analisis regresi linear diperoleh persamaan garis $\ln \mathrm{k}=165,2(1 / \mathrm{T})$ $-0,205$ dengan $r=0,3$.

Nilai slope dari persamaan garis ini merupakan nilai -E/R dari persamaan Arrhenius, sehingga nilai -E/R adalah 165,2 ${ }^{0} \mathrm{~K}$, jika dikalikan dengan nilai $\mathrm{R}$ (konstanta gas), yaitu 1,986 kal/mol, diperoleh nilai energi aktivasi (E) sebesar 328,0872 $\mathrm{kal} / \mathrm{mol}$. 


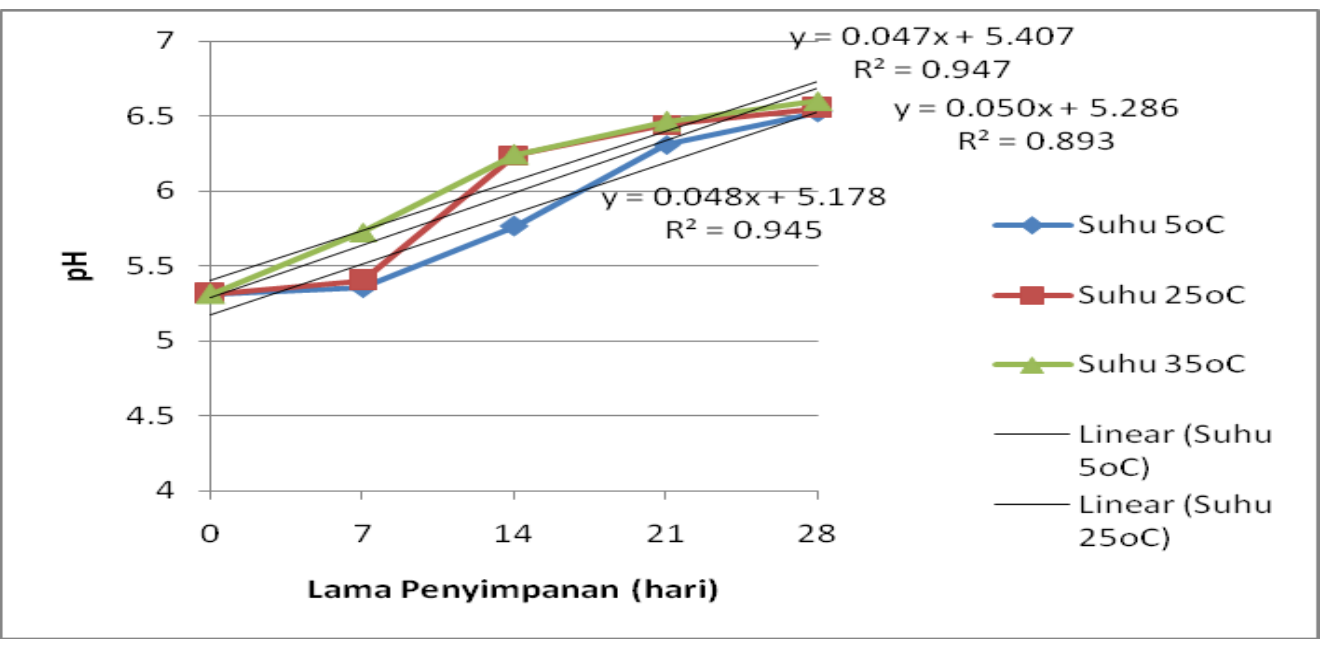

Gambar 6. Grafik Hubungan antara Lama Penyimpanan dengan pH Sirup Temulawak, Madu dan Ekstrak Ikan Gabus

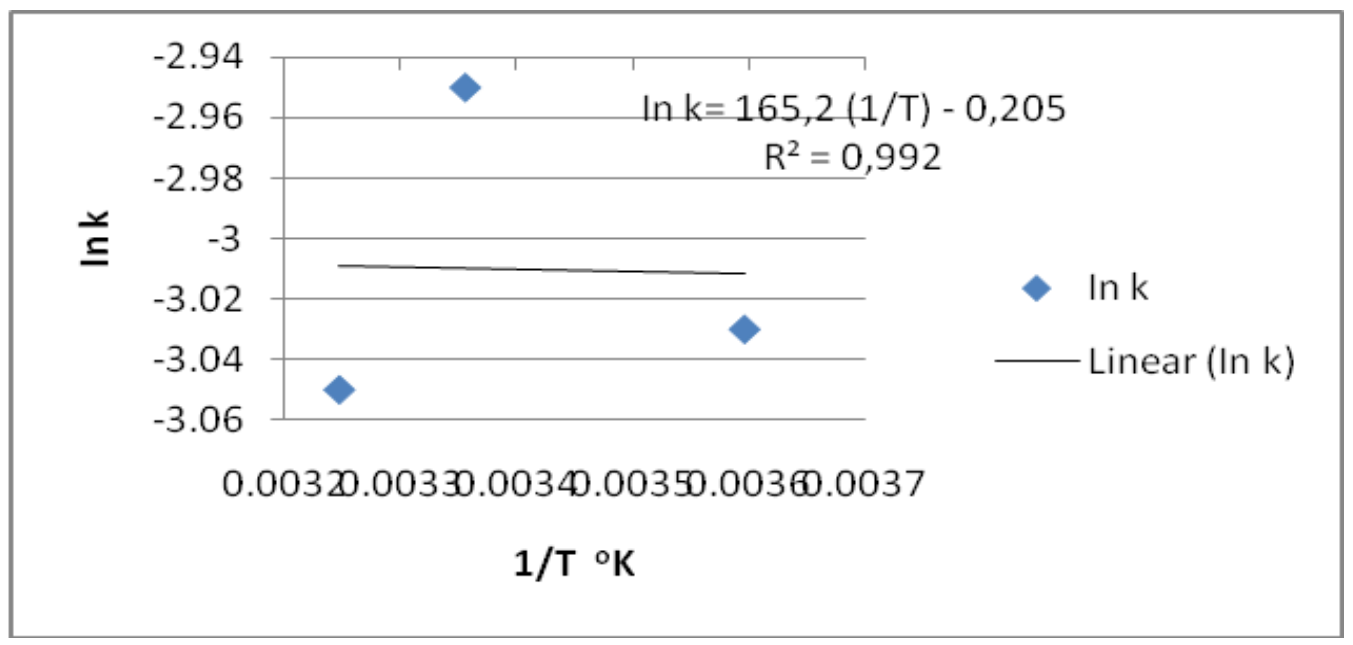

Gambar 7. Hubungan antara ln k dan 1/T

Tabel 4. Laju Peningkatan Nilai pH Sirup Temulawak, Madu dan Ekstrak Ikan Gabus

\begin{tabular}{lcc}
\hline \multicolumn{1}{c}{ Suhu } & \multicolumn{1}{c}{ Persamaan } & $\begin{array}{c}\mathbf{k}(\text { derajat } \\
\text { keasaman/ml/hr) }\end{array}$ \\
\hline $5^{\circ} \mathrm{C}$ atau $278^{\circ} \mathrm{K}$ & $\mathrm{k}=0,814647316 . \mathrm{e}^{-165,2 \times(1 / 278)}$ & 0,44977 \\
$25^{\circ} \mathrm{C}$ atau $298^{\circ} \mathrm{K}$ & $\mathrm{k}=0,814647316 . \mathrm{e}^{-165,2 \times(1 / 298)}$ & 0,46813 \\
$35^{\circ} \mathrm{C}$ atau $308^{\circ} \mathrm{K}$ & $\mathrm{k}=0,814647316 . \mathrm{e}^{-165,2 \times(1 / 308)}$ & 0,47663 \\
\hline
\end{tabular}

Nilai intersep merupakan nilai ko dari persamaan Arrhenius, sehingga diperoleh nilai ko (konstanta tidak tergantung suhu) sebesar $0,814647316 \mathrm{mmol} / \mathrm{kg} / \mathrm{hr}$. Jadi persamaan Arrhenius untuk laju perubahan
$\mathrm{pH}$ sirup temulawak, madu dan ekstrak ikan gabus adalah $\mathrm{k}=0,814647316 . \mathrm{e}^{-165,2 \times(1 / \mathrm{T}}$ dalam Kelvin). Berdasarkan persamaan Arrhenius tersebut, dapat ditentukan laju 
peningkatan $\mathrm{pH}$ pada berbagai suhu penyimpanan seperti Tabel 4

Perhitungan lebih lanjut dari model Arrhenius adalah model $\mathrm{Q}_{10}$ disajikan pada Tabel 5.

Tabel 5. Faktor Percepatan Reaksi $\left(\mathbf{Q}_{10}\right)$ pH Sirup Temulawak, Madu dan Ekstrak Ikan Gabus

\begin{tabular}{lc}
\hline Suhu & $\mathbf{Q}_{10}$ \\
\hline$-5^{\circ} \mathrm{C}$ atau $268^{\circ} \mathrm{K}$ & 1,02266 \\
$0^{\circ} \mathrm{C}$ atau $273^{\circ} \mathrm{K}$ & 1,02160 \\
$5^{\circ} \mathrm{C}$ atau $278^{\circ} \mathrm{K}$ & 1,02061 \\
$25^{\circ} \mathrm{C}$ atau $298^{\circ} \mathrm{K}$ & 1,01815 \\
$35^{\circ} \mathrm{C}$ atau $308^{\circ} \mathrm{K}$ & 1,01663 \\
\hline
\end{tabular}

dalam berbagai suhu (Syarief dan Halid, 1993).

Perhitungan masa kadaluarsa produk berdasarkan parameter $\mathrm{pH}$ yang disimpan pada suhu $-5^{\circ} \mathrm{C}$ dan $0^{\circ} \mathrm{C}$ dengan menggunakan model $\mathrm{Q}_{10}$ relatif sama yaitu 12 hari.

Estimasi pendugaan umur simpan berdasarkan laju pertumbuhan total mikroorganisme sirup temulawak, madu dan ekstrak ikan gabus

Grafik laju peningkatan nilai total mikroorganisme dapat dilihat pada Gambar 8.

Dengan menggunakan Model $\mathrm{Q}_{10}$ ini dapat dihitung estimasi umur simpan produk

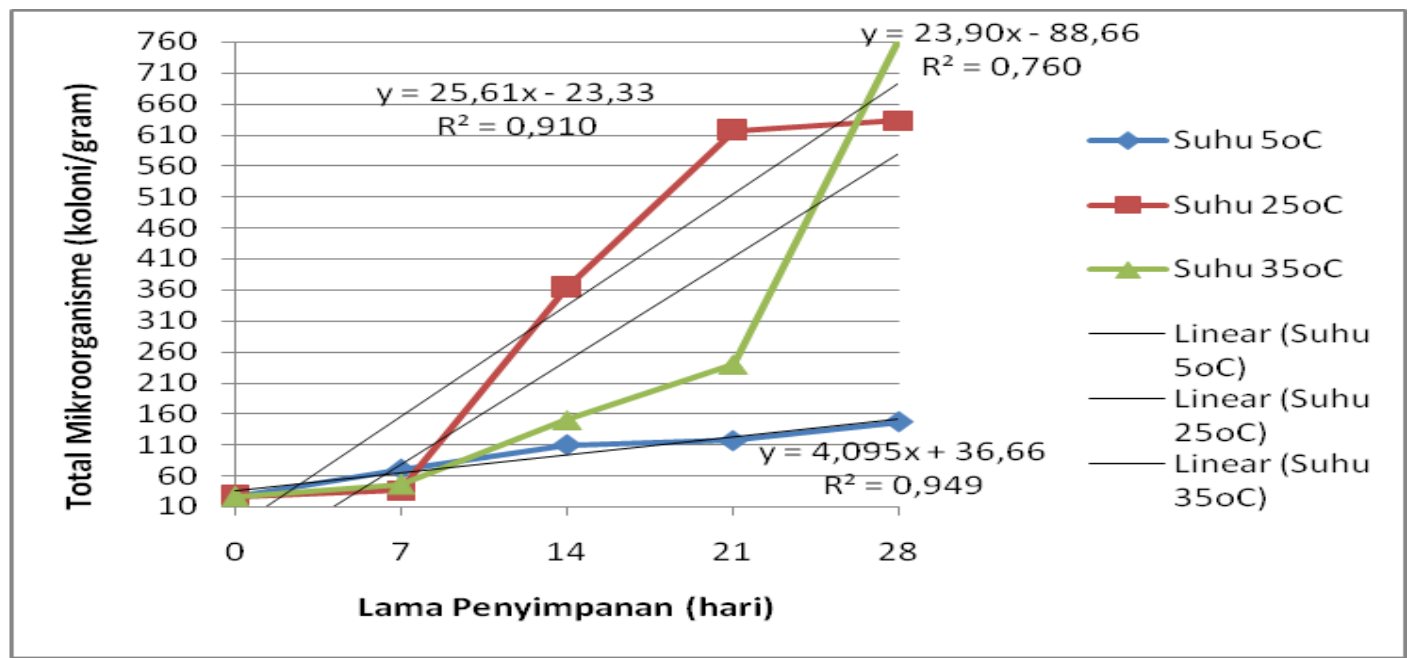

Gambar 8. Grafik Hubungan antara Lama Penyimpanan dengan Total Mikroorganisme Sirup Temulawak, Madu dan Ekstrak Ikan Gabus

Nilai konstanta penurunan mutu pada ketiga suhu penyimpanan tersebut kemudian diterapkan pada persamaan Arrhenius yaitu $\ln \mathrm{k}=\ln \mathrm{ko}-\mathrm{E} / \mathrm{RT}$. Setiap nilai ln $\mathrm{k}$ dan 1/T (satuan suhu dalam Kelvin) pada masing masing suhu penyimpanan diplotkan sebagai ordinat dan absis. Grafik hubungan nilai ln $\mathrm{k}$ dan $1 /$ T produk sirup temulawak, madu dan ekstrak ikan gabus dapat dilihat pada gambar 9. Dari analisis regresi linear diperoleh persamaan garis $\ln \mathrm{k}=-5477(1 / \mathrm{T})$ $+21,22$ dengan $r=0,94$. Nilai slope dari persamaan garis ini merupakan nilai -E/R dari persamaan Arrhenius, sehingga nilai E/R adalah $-5477^{\circ} \mathrm{K}$, jika dikalikan dengan nilai R (konstanta gas), yaitu 1,986 kal/mol, diperoleh nilai energi aktivasi (E) sebesar $10877,322 \mathrm{kal} / \mathrm{mol}$. Jadi besarnya energi kinetik minimal yang dibutuhkan molekul dalam sirup temulawak, madu dan ekstrak 
ikan gabus untuk meningkatkan total kalori/mol. mikroorganisme adalah sebesar 10877,322

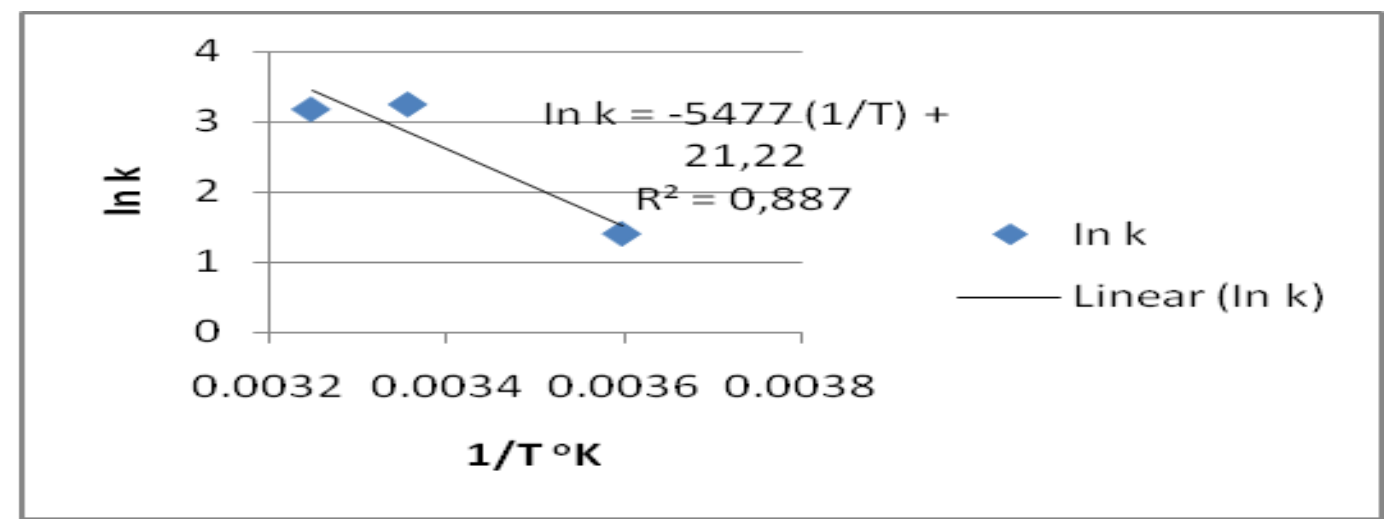

Gambar 9. Hubungan antara ln k dan 1/T

Tabel 6. Laju Peningkatan Jumlah Total Mikroorganisme Sirup Temulawak, Madu dan Ekstrak Ikan Gabus

\begin{tabular}{ccc}
\hline \multicolumn{1}{c}{ Suhu } & Persamaan & k (koloni/g//hr) \\
\hline $5^{\circ} \mathrm{C}$ atau $278^{\circ} \mathrm{K}$ & $\mathrm{k}=1643345599 . \mathrm{e}^{-5477 \times(1 / 278)}$ & 4,57222 \\
$25^{\circ} \mathrm{C}$ atau $298^{\circ} \mathrm{K}$ & $\mathrm{k}=1643345599 . \mathrm{e}^{-5477 \times(1 / 298)}$ & 17,12955 \\
$35^{\circ} \mathrm{C}$ atau $308^{\circ} \mathrm{K}$ & $\mathrm{k}=1643345599 . \mathrm{e}^{-5477 \times(1 / 308)}$ & 31,18695
\end{tabular}

Nilai persamaan Arrhenius untuk laju perubahan jumlah total mikroorganisme adalah $\mathbf{k}=1643345599 . \mathrm{e}^{-5477 \times}$ (1/T dalam Kelvin). Berdasarkan persamaan Arrhenius tersebut, dapat ditentukan laju peningkatan pH pada berbagai suhu penyimpanan seperti pada Tabel 6. Setelah mendapatkan laju peningkatan total mikroorganisme, maka umur simpan sirup pada suhu penyimpanan yang berbeda dapat dihitung.

Tabel 7. Faktor Percepatan Reaksi $\left(Q_{10}\right)$ Jumlah Mikroorganisme Sirup Temulwak, Madu dan Ekstrak Ikan Gabus

\begin{tabular}{lc}
\hline Suhu & $\mathbf{Q}_{\mathbf{1 0}}$ \\
\hline$-5^{\circ} \mathrm{C}$ atau $268^{\circ} \mathrm{K}$ & 2,08875 \\
$0^{\circ} \mathrm{C}$ atau $273^{\circ} \mathrm{K}$ & 2,03178 \\
$5^{\circ} \mathrm{C}$ atau $278^{\circ} \mathrm{K}$ & 1,97909 \\
$25^{\circ} \mathrm{C}$ atau $298^{\circ} \mathrm{K}$ & 1,82065 \\
\hline
\end{tabular}

$35^{\circ} \mathrm{C}$ atau $308^{\circ} \mathrm{K} \quad 1,74495$

Dengan menggunakan Model $\mathrm{Q}_{10}$ ini dapat dihitung estimasi umur simpan produk dalam berbagai suhu (Syarief dan Halid, 1993), misalnya pada suhu $-5^{\circ} \mathrm{C}$ dan $0^{\circ} \mathrm{C}$ (suhu beku) yang diasumsikan sebagai suhu penyimpanan untuk pendistribusian produk.

Perhitungan masa kadaluarsa produk berdasarkan parameter total mikroorganisme yang disimpan pada suhu $-5^{\circ} \mathrm{C}$ dengan menggunakan model $\mathrm{Q}_{10}$ adalah 18 hari dan yang disimpan pada suhu $0^{\circ} \mathrm{C}$ adalah 12 hari.

Dari hasil perhitungan estimasi umur simpan dengan menggunakan metode Arrhenius terdapat perbedaan umur simpan dengan menggunakan beberapa parameter yang dapat dilihat pada Tabel 8. 
Tabel 8. Umur simpan sirup temulawak, madu dan ekstrak ikan gabus dengan model Arrhenius

\begin{tabular}{lccc}
\hline Suhu & $\begin{array}{c}\text { Umur simpan } \\
\text { (parameter total } \\
\text { padatan terlarut) }\end{array}$ & $\begin{array}{c}\text { Umur simpan } \\
\text { (parameter } \mathrm{pH})\end{array}$ & $\begin{array}{c}\text { Umur simpan (parameter total } \\
\text { mikroorganisme) }\end{array}$ \\
\hline $5^{\circ} \mathrm{C}$ & 46 hari & 12 hari & 9 hari \\
$25^{\circ} \mathrm{C}$ & 45 hari & 12 hari & 3 hari \\
$35^{\circ} \mathrm{C}$ & 45 hari & 11 hari & 1 hari \\
\hline
\end{tabular}

Hasil perhitungan pendugaan, semakin tinggi suhu penyimpanan, umur simpan produk semakin pendek. Hal ini diduga karena terjadi kerusakan akibat reaksi pencoklatan non-enzimatis dan pertumbuhan mikroorganisme yang semakin meningkat. Labuza (1982) dalam Simammora (2011) menyatakan bahwa reaksi pencoklatan nonenzimatis dapat terjadi pada suhu tinggi dan menurut Buckle (1985) apabila suhu naik, kecepatan metabolisme mikroba akan naik dan pertumbuhan dipercepat.

Upaya memperpanjang umur simpan dapat dilakukan dengan beberapa cara yaitu meningkatkan nilai mutu dan memperlambat laju penurunan mutu. Oleh karena itu, pengolahan produk pangan untuk memperpanjang umur simpan perlu memperhatikan faktor lain yang dapat menimbulkan kerusakan mutu (Herawati, 2008).

Karakteristik kemasan juga mempengaruhi laju penurunan mutu, pada penelitian ini kemasan yang digunakan untuk produk adalah kemasan PETE atau PET (Polyethylene Terephthalate) yang merupakan plastik kaku, tembus pandang, memiliki daya perlindungan terhadap gas dan uap air baik dan relatif tahan terhadap panas (Kristianto, 2010). Jenis permeabilitas film tergantung pada bahan pangan yang digunakan, permeabilitas film PE (polyethylene) lebih kecil daripada PP (polyprophylene). Hal ini menunjukkan bahwa gas atau uap air akan lebih mudah rusak pada bahan pengemas jenis PP daripada PE (Herawati, 2008).
Keuntungan menggunakan kemasan PET ini adalah kemampuannya untuk ditutup sehingga memberi tutup yang rapat terhadap cairan (Buckle, 1985).

\section{Sifat Organoleptik Sirup Temulawak, Madu dan Ekstrak Ikan Gabus Warna Sirup}

Sirup yang disimpan selama 4 minggu semakin lama warnanya cenderung berubah menjadi semakin pekat yang disebabkan karena adanya perubahan reaksi kimia yaitu reaksi Maillard yang menyebabkan warna menjadi.

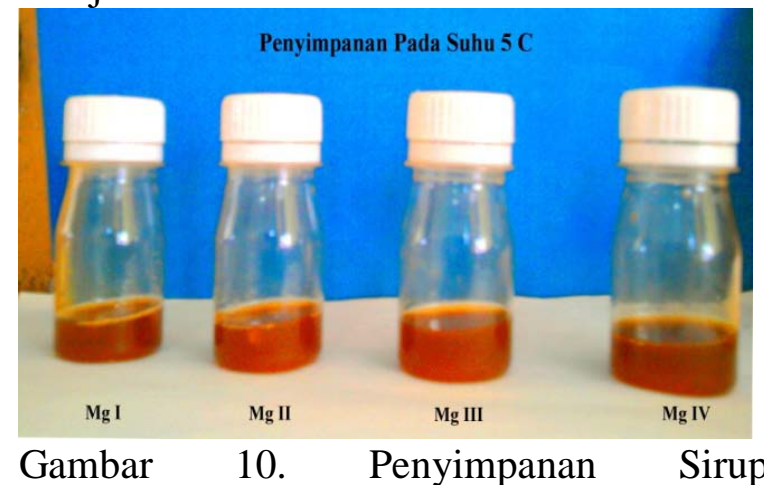

Temulawak, Madu dan Ekstrak kan Gabus Pada Suhu Penyimpanan $5^{0} \mathrm{C}$ Selama 4 Minggu

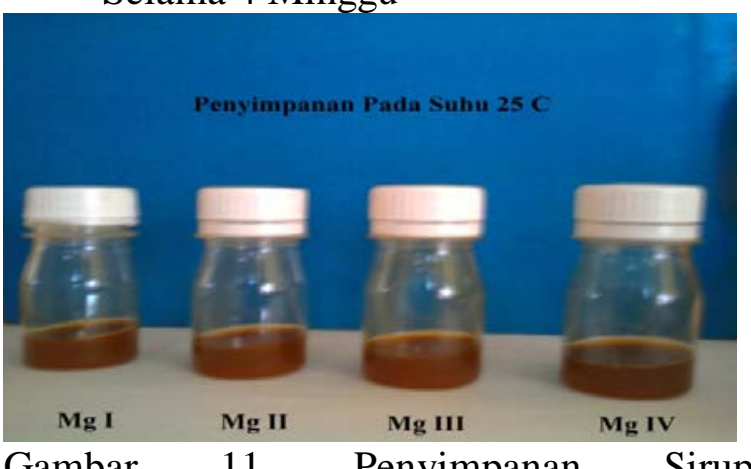

Temulawak, Madu dan Ekstrak kan 
Gabus Pada Suhu Penyimpanan $25^{\circ} \mathrm{C}$ (Suhu Ruang) Selama 4 Minggu

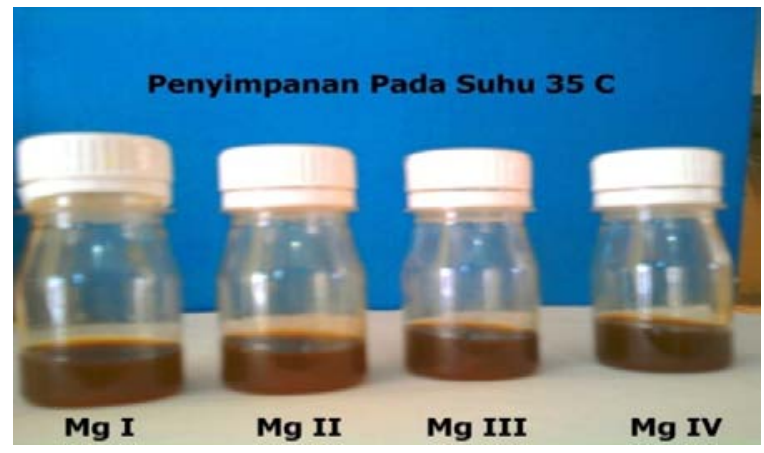

Gambar 12. Penyimpanan Sirup Temulawak, Madu dan Ekstrak kan Gabus Pada Suhu Penyimpanan $35^{\circ} \mathrm{C}$ Selama 4 Minggu

Gambar 10, 11, dan 12 menunjukan perbedaan warna antara sirup temulawak, madu dan ekstrak ikan gabus yang disimpan pada pada 3 macam suhu penyimpanan yaitu $5^{\circ} \mathrm{C}, 25^{\circ} \mathrm{C}$, dan suhu $35^{\circ} \mathrm{C}$. Pada minggu pertama warnanya lebih terang dan semakin lama disimpan maka warnanya semakin gelap (pekat). Menurut Muchtadi (2010), penyebab dari perubahan warna disebabkan oleh reaksi kimia gula dan asam amino dari protein yang dikenal sebagai reaksi pencoklatan (browning) atau reaksi Maillard. Reaksi Maillard terjadi bila bahan pangan mengalami pemanasan atau penyimpanan. Beberapa reaksi Maillard dapat menyebabkan warna kehitaman atau bau tidak sedap pada makanan tidak diharapkan (Afrianto, dkk., 2008).

Perubahan warna pada suatu produk bahan pangan yang telah disimpan juga diakibatkan karena adanya pertumbuhan mikroorganisme pada bahan pangan tersebut. Menurut Buckle (1985) beberapa mikroorganisme menghasilkan kolonikoloni yang berwarna atau mempunyai pigmen (zat warna) Sedangkan pada bahan pangan berkadar gula tinggi seperti halnya sirup.
Gambar 10, sirup temulawak yang disimpan pada suhu dingin yaitu $5^{\circ} \mathrm{C}$ memiliki warna yang lebih terang, hal ini dikarenakan penyimpanan pada suhu dingin akan menghambat aktivitas enzim sehingga reaksi kimia yang terjadi akan lebih lambat dan pertumbuhan mikroorganisme juga terhambat. Disampaikan oleh Santoso (2006) bahwa penyimpanan pada suhu rendah dapat memperpanjang masa hidup jaringan-jaringan dalam bahan pangan tersebut karena aktivitas respirasi menurun dan menghambat aktivitas mikroorganisme.

Pada Gambar 11, sirup temulawak yang disimpan pada suhu ruang yaitu $25^{\circ} \mathrm{C}$ memiliki warna yang lebih pekat dibandingkan dengan sirup yang disimpan pada suhu dingin, hal tersebut dapat diakibatkan karena pada suhu ruang sehubungan dengan pengaruh suhu terhadap ketahanan hidup mikroorganisme, pemanasan atau kenaikan suhu bersifat jauh lebih merusak daripada pendinginan (Buckle, 1985).

Pada Gambar 12, sirup yang disimpan pada suhu $35^{\circ} \mathrm{C}$ dan dengan rata - rata $\mathrm{pH}$ 6,0 memiliki warna yang lebih pekat dibandingkan dengan sirup yang disimpan pada suhu $5^{\circ} \mathrm{C}$ dan $25^{\circ} \mathrm{C}$ karena sirup yang disimpan pada suhu $35^{\circ} \mathrm{C}$ mendekati suhu dan $\mathrm{pH}$ optimal pertumbuhan Aspergillus niger, (Laskin dkk.,, 1988, dalam Marlina, dkk, 2008).

\section{Aroma}

Hasil uji aroma sirup selama 4 minggu, mulai minggu pertama hingga minggu ketiga masih khas aroma temulawak, namun pada minggu keempat aroma temulawak sudah mulai memudar. Hal ini disebabkan karena tumbuhnya bakteri, khamir, atau kapang di dalam bahan pangan yang dapat mengubah komposisi bahan pangan, menghidrolisa pati dan selulosa atau menyebabkan fermentasi gula, sedangkan lainnya dapat menghidrolisa 
lemak dan menyebabkan ketengikan atau dapat mencerna protein dan menghasilkan bau busuk dan amoniak (Muchtadi, 2010).

\section{Kekentalan}

Dalam produk sirup temulawak, madu dan ekstrak ikan gabus terkandung pati yang dari temulawak yang berbentuk granula (butir). Granula pati dapat berubah membengkak ke luar yang disebut dengan gelatinisasi, gelatinisasi memiliki suhu gelatinisasi yaitu suhu pada saat graula pati pecah. Makin kental larutan, suhu tersebut makin lambat tercapai, sampai suhu tertentu kekentalan tidak bertambah, bahkan kadang-kadang turun. Penambahan gula juga berpengaruh pada kekentalan gel yang membentuk. Gula akan menurunkan kekentalan, hal ini disebabkan gula akan mengikat air sehingga pembengkakan butir - butir pati terjadi lebih lambat, akibatnya suhu gelatinisasi lebih tinggi (Winarno, 2004).

\section{KESIMPULAN DAN SARAN}

\section{Kesimpulan}

Sirup temulawak, madu dan ekstrak ikan gabus disimpan selama 4 minggu pada suhu $5^{\circ} \mathrm{C}, 25^{\circ} \mathrm{C}$ dan $35^{\circ} \mathrm{C}$. Hasil pengamatan terhadap total padatan terlarut didapatkan semakin lama disimpan semakin menurun. Pada minggu ke 0 sebelum penyimpanan rata - rata total padatan terlarut sirup 63,43 \%Brix dan terus mengalami penurunan hingga minggu ke 4 yaitu sirup yang disimpan pada suhu $5^{\circ} \mathrm{C}$ adalah 57,5 \%Brix, pada suhu $25^{\circ} \mathrm{C}$ menurun hingga 54,6 \%Brix, dan pada suhu $35^{\circ} \mathrm{C}$, mencapai $57,8 \%$ Brix.

$\mathrm{pH}$ sirup selama penyimpanan semakin meningkat. Pada awal penyimpanan diketahui $\mathrm{pH}$ sirup : 5,31 dan terus meningkat hingga minggu ke 4 mencapai 6,52 pada suhu $5^{\circ} \mathrm{C}, 6,55$ pada suhu $25^{\circ} \mathrm{C}$ dan 6,6 pada suhu $35^{\circ} \mathrm{C}$. Peningkatan $\mathrm{pH}$ berkisar antara 0,1-0,8.

Total mikroorganisme sirup selama disimpan semakin meningkat yaitu pada awal penyimpanan diketahui total

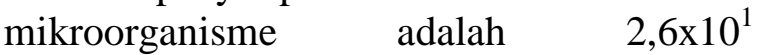
koloni/gram. Pada minggu ke 4 jumlah total mikroorganisme tertinggi adalah pada suhu

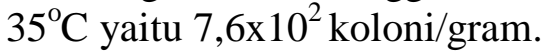

Estimasi pendugaan umur simpan sirup temulwak, madu dan ekstrak ikan gabus menggunakan model Arrhenius, berdasarkan parameter total padatan terlarut, yatu selama 46 hari pada suhu $5^{\circ} \mathrm{C}, 45$ hari pada suhu $25^{\circ} \mathrm{C}$, dan 44 hari pada suhu $35^{\circ} \mathrm{C}$. Berdasarkan parameter $\mathrm{pH}$ estimasi umur simpan sirup temulwak, madu dan ekstrak ikan gabus adalah 12 hari pada suhu $5^{\circ} \mathrm{C}, 11$ hari pada suhu $25^{\circ} \mathrm{C}$ dan $35^{\circ} \mathrm{C}$. Dan berdasarkan parameter total mikroorganisme, diperoleh hasil estimasi umur simpan sirup temulwak, madu dan ekstrak ikan gabus adalah 9 hari pada suhu $5^{\circ} \mathrm{C}$, 3 hari pada suhu $25^{\circ} \mathrm{C}$, dan 1 hari pada suhu $35^{\circ} \mathrm{C}$. Jadi umur simpan sirup temulawak, madu dan ekstrak ikan gabus dengan penyimpanan $5^{\circ} \mathrm{C}, 25^{\circ} \mathrm{C}$, dan $35^{\circ} \mathrm{C}$ berturut-turut menggunakan model Arrhenius adalah 9 hari, 3 hari dan 1 hari. Sedangkan dengan menggunakan model $\mathrm{Q}_{10}$ untuk sirup yang disimpan pada suhu beku yang diasumsikan sebagai suhu penyimpanan untuk pendistribusian produk, maka masa kadaluarsa produk sirup ini pada suhu $-5^{\circ} \mathrm{C}$ adalah 18 hari dan $0^{\circ} \mathrm{C}$ adalah 12 hari.

\section{Saran}

Pendugaan umur simpan menggunakan metode ASLT dengan model Arrhenius sirup temulawak, madu dan ekstrak ikan gabus hanya dilihat dari parameter total padatan terlarut, $\mathrm{pH}$ dan total mikroorganisme sehingga perlu adanya penelitian lanjutan tentang pendugaan umur simpan dengan parameter lain seperti kadar 
air serta reaksi oksidasi, dan dapat pula menggunakan metode pendugaan umur simpan lain seperti Kurva Isotermi Sorpsi Air.

\section{DAFTAR PUSTAKA}

Afrianto, E., dkk. 2008. Pengawasan Mutu Bahan / Produk Pangan. Jakarta : Departemen Pendidikan Nasional.

Buckle, K. A. 1985. Ilmu Pangan. Jakarta : UI Press.

Fardiaz, S. 1992. Mikrobiologi Pangan. Jakarta : Gramedia Pustaka Utama.

Fardiaz, S. 1993. Analisis Mikrobiologi Pangan. Jakarta : Raja Grafindo Persada.

Gaman, P. M dan K. B. Sherrington. 1992. Ilmu Pangan - Pengantar Ilmu Pangan Nutrisi dan Mikrobiologi. Yogyakarta : Gadjah Mada University Press.

Haarow, B. 1943. Textbook of Biochemistry hal.79-80. Philadelphia : W.B Saunders Company.

Herawati, H. 2008. Penentuan Umur Simpan pada Produk Pangan. Ungaran : Jurnal Litbang Pertanian.

Histifarina, D. 2004. Pendugaan Umur Simpan Kentang Tumbuk Instan Berdasarkan Kurva Isotermi Sorpsi Air dan Stabilitasnya Selama Penyimpanan. Bandung : Jurnal Hortikultura.

Kristianto, Y. 2010. Panduan Memilih dan Belanja Makanan Sehat. Yogyakarta : Nailil Printika.

Kusnandar, F. 2010. Pendugaan Umur Simpan Propooduk Pangan dengan Metode Accelerated Shelf Life Testing (ASLT). Institut Pertanian Bogor.

Muchtadi, T.R. 1992. Ilmu Pengetahuan Bahan Pangan. Bogor : Pusat Antar Universitas Pangan dan Gizi.
Muchtadi, T.R. 2010. Teknologi Proses Pengolahan Pangan. Bandung : AlfaBeta.

Rusli, dkk. 2006. Terapi Albumin Dalam Ekstrak Ikan Gabus Terhadap Kerusakan Hati Tikus Putih. Makassar : Jurnal Kesehatan.

Santoso, SP. 2006. Teknologi Pengawetan Bahan Segar. Malang : Naskah Publikasi Uwiga.

Simmamora, J. H. 2011. Identifikasi Teknik Pengolahan dan Pendugaan Umur Simpan Udang Kering Tanpa Kulit. Bogor : Naskah Publikasi Institut Pertanian Bogor.

Syarief, R. dan Hariyadi H. Teknologi Penyimpanan Pangan. 1993. Jakarta : Arcan.

Tawali, A.B., dkk. 2004. Pengaruh Suhu Penyimpanan terhadap Mutu Buah buahan Impor yang Dipasarkan di Sulawesi Selatan. Sulawesi selatan : Naskah Publikasi Jurusan Teknologi Hasil Pertanian UNHAS.

Winarno, F. G. 2004. Keamanan Pangan Jilid 1. Bogor : Mbrio Press.

Winarno, F. G. 2004. Kimia Pangan dan Gizi. Jakarta : Gramedia Pustaka Utama.

Winarno, F. G. 2007. Teknobiologi Pangan. Bogor : Mbrio Press. 